\title{
The Tormentor from Torun's Fort VII, Karl Friedrich Strauss, on the Defendant Bench
}

\author{
Kat toruńskiego Fortu VII, Karl Friedrich Strauss \\ na ławie oskarżonych
}

\section{- Abstrakt •}

Artykuł poświęcony jest procesowi Karla Friedricha Straussa, który od końca października 1939 do stycznia 1940 roku pełnił funkcję komendanta administracyjnego toruńskiego Fortu VII, w którym funkcjonował obóz dla internowanych osób cywilnych (Zivilinternierungslager), a ponadto uczestniczył w egzekucjach Polaków w podtoruńskim lesie Barbarka. Proces Straussa odbył się w czerwcu 1969 roku przed sądem przysięgłych w zachodnioberlińskiej dzielnicy Moabit. Był on szeroko komentowany na łamach pomorskiej prasy i jest to podstawowe źródło, na podstawie którego powstał niniejszy artykuł. Proces Straussa to jeden z licznych przykładów klęski denazyfikacji w powojennych Niemczech. Mimo że zbrodnie popełnione przez byłego komendanta toruńskiego Fortu VII nie ulegają wątpliwości, to jednak pobłażliwość niemieckiego wymiaru sprawiedliwości sprawiła, że jeden z największych oprawców więźniów toruńskiego Fortu VII nie poniósł kary.

\section{- Abstract •}

The paper focuses on the trial of Karl Friedrich Strauss, who from the end of October 1939 until January 1940 served as the administrative commandant of Fort VII in Toruń, which hosted an internment camp for civilians (Zivilinternierungslager). Strauss also participated in executions of Poles in the Barbarka forest near Torun. The Strauss trial was a trial by jury which took place in June 1969 in the West Berlin district of Moabit. The legal proceedings were widely commented on in the pages of the Pomeranian press, and these press articles serve as the main source material for the present paper. The Strauss trial is one of numerous examples of failure of the denazification process in post-war Germany. Although the crimes committed by the former commander of Toruńs Fort VII were not in any doubt, the leniency of the German judicial system meant that in the end one of the greatest tormentors of those imprisoned in Fort VII escaped justice and was not punished. 
Słowa kluczowe: II wojna światowa; okupacja niemiecka; Toruń; Fort VII; Barbarka; Karl Friedrich Strauss; zbrodnie nazistowskie; denazyfikacja; procesy zbrodniarzy nazistowskich
Keywords: World War II; German occupation; Toruń; Fort VII; Barbarka; Karl Friedrich Strauss; Nazi crimes; denazification; trials of Nazi war criminals

The signing of the act of unconditional surrender by Germany on May 7, 1945 in Reims opened a new chapter in the history of that country. The German nation was liberated from the tyranny of national socialism ${ }^{1}$, but the tragic legacy of the Third Reich was the necessity of reckoning with its painful past, in the first place as concerned the crimes committed by the Nazis. Unfortunately, the final balance of the post-war process of denazification, including prosecution and punishment of Nazi war criminals is definitely negative, as only a minority of them were ever made to face justice for their deeds. Some of the criminals found shelter in Latin America, while others were treated by the justice system with extreme leniency and were often acquitted or given very low sentences, completely misaligned with the seriousness of the crimes committed (For more, see: Vollnhals \& Schlemmer, 1991; Frei, 1999, Sołga, 2004, Wahl, 2009, Taylor, 2016). One of those that remained unpunished was Karl Friedrich Strauss, who from the end of October 1939 to January 1940 served as the administrative commandant of Toruńs Fort VII, where the civilian internment camp (Zivilinternierungslager) operated.

Karl Friedrich Strauss was born on July 9, 1911 in Toruń, as son of Wilhelm and Olga née Lüdtke. After apprenticing in carpentry, in the years 1933-1935 he served in the Polish army, ultimately leaving it as non-commissioned officer. Then he opened a carpentry workshop in Torun at Piaskowa Street (Gazeta Pomorska (5.06.1969), 132, 1-2). According to the inhabitants of Torun (this and further newspaper and archival quotes translated from Polish by the author): "Before the war, he was a frequent guest at the German consulate, where he was reporting 'all the news' from the city. He often frequented Catholic churches and listened to sermons (as he knew Polish well), diligently writing down what was being said. He lived in Podgórze and, as a citizen of the Polish state, initially - i.e. before the war - did not flaunt his attachment to the 'Führer' and fascism too much. It was only after the occupation of Torun by the Wehrmacht that he stopped with the pretence, becoming the terror of the city and its surroundings" (Gazeta Pomorska (7/8.06.1969), 134, 7). Soon after the occupation of Torun by the German troops - which took place on September 7, 1939 - Strauss became an officer with the Auxiliary Police Forces (Hilfspolizei), formed at the initiative of Rudolf

${ }^{1}$ For more information on nazi policy see inter alia in: Grochowina \& Kącka (2014, pp. 173$-192)$. 
Preuss, a German citizen. At the end of October 1939 as a member of Selbstschutz, a police formation made up of local Germans (for more see, inter alia: Bojarska, 1979; Jansen \& Weckbecker, 1992; Mazanowska \& Ceran, 2016), Strauss became the administrative commendant of Fort VII, in which the so-called civilian internment camp operated. It was the central place of detainment of Poles, mass arrested in Torun city and the surrounding poviat in October 1939. According to the accounts of former prisoners of Fort VII, Strauss was their greatest tormentor.

On December 29, 1947, the District Investigative Judge in Toruń J. Becker issued a warrant for temporary arrest of Karl Friedrich Strauss, with suspected place of residence in the Soviet occupation zone, in Thuringia. The warrant which was justified by the following: "Karol Strauss is suspected of an offense under Art. 1 of PKWN (Polish Committee of National Liberation, PCNL) decree of August 31, 1944 (PCLN Decree "On the punishment of Nazi-Fascist criminals guilty of murder and ill-treatment of civilians and prisoners of war and of traitors to the Polish nation") as per the wording of the uniform text made public in the Announcement of the Minister of Justice of 11 December 1946 (Journal of Laws No. 69 item 377), consisting namely in the fact that, aiding the German occupants, in the period from the end of October 1939 to the end of February 1940 in Torun he served as commander of Fort VII, in which Poles were imprisoned on the grounds of political views and nationality, and actively participated in torture and torment of the detainees, and is responsible for torture, ill-treatment and murder of many Poles interned in the Fort" (Archives of the Institute of National Remembrance (AINR), reference GK 164/608, vol. 1, warrant for temporary arrest of KF Strauss of 29.12.1947).

On January 23, 1948, the prosecutor of the District Court in Torun, Szaniawski, sent an extradition request in the case of KF Strauss to the Ministry of Justice. The crimes committed by Strauss against the prisoners of Toruńs Fort VII were described as follows: "At the end of October [1939] Karol Friedrich Strauss became the commander of the Fort; he was assisted by armed German civilians. After Strauss took up this position, the treatment of prisoners has changed considerably for the worse. At every opportunity, he denigrated the Poles, and abused and beat them without mercy, often until they lost consciousness (...). One day in the winter of 1939/1940, Strauss ordered prisoners to ride on their buttocks down a hillside, where barbed wire covered with snow was spread over a $5 \mathrm{~m}$ stretch. People rushing down that way were hurt deeply and their clothing was shredded. Strauss often organized penal exercises in the courtyard of the Fort, in which prisoners had to run up and down slopes covered with ice, dropping down and getting up on command. During the exercises many people were slipping and 
falling painfully, getting hurt. Strauss kicked and beat one of the prisoners that fell down from exhaustion and could not get up. A place of execution and torture of imprisoned Poles was located on the $1^{\text {st }}$ floor of Fort VII buildings. This was where, upon Strauss' orders, prisoners were brought in and tortured; their moans and screams could be heard downstairs. Those people did not come back to their assigned cells as they were transported out of the Fort. Such transports were taking place at night (AINR, reference GK 351/161, extradition request in the case of K.F. Strauss of 21.01.1948)".

In the end, K. Strauss was not extradited. The main court proceedings in the criminal trial against the former commandant of Fort VII in Torun took place over twenty years later in front of a jury in the West Berlin district of Moabit and lasted - on and off - from June 4 to 27, 1969 (Gazeta Pomorska (5.06.1969), 132, 1-2; Jaszowski \& Sobecki, 1971, p. 87). Incidentally, it is worth mentioning that on March 25, 1969 in Torun the District Commission for Investigation of Nazi Crimes in Bydgoszcz and the District Board of the League of Fighters for Freedom and Democracy (ZBoWiD) in Bydgoszcz organized at the Youth Culture Center at Przedzamcze Street 1 a public press conference exposing German crimes committed in Toruńs Fort VII and in the forest of Barbarka. Direct witnesses of these crimes were among participants of the session. The conference was led by the chairman of the District Commission for Investigation of Nazi Crimes and president of the Provincial Court Marian Szabela, judge Władysław Solecki and prosecutor Tadeusz Jaszowski. During the conference they made a clear appeal: "There can be no statute of limitations for Nazi crimes" (Gazeta Pomorska (22/23.03.1969), 69, 7; (25.03.1969), 71, 1; (26.03.1969), 72, 1-2; (29/30.03.1969), 75, 7).

Strauss' indictment read as follows: "In the period from September to the end of November 1939 in Toruń (Poland) (...) as a member of Selbstschutz (...) he participated in five mass executions of at least eighty Polish prisoners of war, ordered and organized by the SS-Sturmbannführer, of which three times he was a member of the security commando and twice part of the firing squad. His motivation was revenge on the Polish population and he was aware and accepting of the fact that these killings were intended to decimate the Polish national leadership" (AINR, reference DS 52/67, photocopy of the judgment in the KF Strauss case of June 27, 1969). It is astonishing and at the same time outrageous that in many places in the trial paperwork a reference was made to entirely unsupported and false accounts about abuse and murders allegedly committed by Poles on Germans in the first days of September 1939, with comments about unjust but understandable revenge acts carried out by Selbstschutz members after the German occupation of Torun (Gazeta Pomorska (5.06.1969), 132, 1-2, Jaszowski \& Sobecki, 1971, p. 88). 
The jury was headed by Eberhard Schaffert, with public prosecutor Greiner for prosecution and attorneys Weimann and Krebs-Fleischmann for defense (Gazeta Pomorska (28/29.06.1969), 152, 1-2). As the first testimony was heard KF Strauss himself, who "was keeping up the pretense of innocence" (Gazeta Pomorska (14/15.06.1969), 140,7) and shifted the responsibility for the crimes onto his superior, SS-Sturmbannführer Helmuth Kurt Zaporowicz (son of an official in the Torun public prosecution office from before World War One, who in December 1939 adopted his mother's maiden name, Goerz; see AINR, reference Ok-By Ds. 52/67, certificate of change of name by Helmuth Kurt Zaporowicz dated 13.11.1940), serving as Kreisführer, that is head of Selbstschutz for the city of Torun and the Torun poviat, which formed one organizational unit - a Kreis (Gazeta Pomorska (5.06.1969), 132, 1-2). When recounting what was happening in Fort VII, Strauss admitted that the Poles were detained there without any judicial decision, stating that he personally knew many prisoners and knew about their innocence (Gazeta Pomorska (5.06.1969), 132, 1-2). The former commandant of Toruń Fort VII argued that he had repeatedly asked SS-Sturmbannführer Helmuth Kurt Zaporowicz to release him from the service in Selbstschutz, so that - as he himself claimed - "he would not need to take part in executions prior to which no official court decisions were read" (Gazeta Pomorska (28/29.06.1969), 152, 1-2; see also: Jaszowski \& Sobecki, 1971, p. 96). However, having not been allowed to leave the ranks of Selbstschutz, he was forced to perform his duties, including participating in the shootings of Poles in the Barbarka forest near Torun, as allegedly SS-Sturmbannführer Zaporowicz threatened that every officer of the Selbstschutz refusing to participate in the executions would be executed himself (Gazeta Pomorska (5.06.1969), 132, 1-2). Admitting to having participates in the executions, Strauss tried to convince the judges and jury that he did not aim at the victims but fired his shots instead around them. Trying to minimize his responsibility, Strauss claimed as well that on his own initiative heorganized food deliveries for the prisoners of Fort VII (Gazeta Pomorska (5.06.1969), 132, 1-2; (28/29.06.1969), 152, 1-2) and that together with the Fort's guard Krauze he aided in the escape of four Poles detained there. Czesław Sobecki, special envoy for Gazeta Pomorska, commented on Strauss's trial: "Strauss's confused testimonies aroused the smiles of pity even among some members of the jury and the journalists watching the trial. When put under pressure more and more by the prosecutor in cross-examination, Strauss lost all his nerve and at the end of his last word resorted to playacting, pretending to cry. He counted on the compassion of the small audience and West Berlin's Themis. The latter is, as it turns out, rather lenient even for such criminals" (Gazeta Pomorska (24.06.1969), 148, 1). 
Interestingly, public prosecutor Greiner downplayed Strauss's guild significantly, as "in his long-winded argument (Greinert) suggested clearly that Strauss was murdering on orders and not on his own initiative. The public prosecutor tried to put the blame mainly on fascism itself as a movement which tempted law-abiding Germans to commit crimes. He also reiterated the story thought up by Goebbels about persecution of the German minority in Poland and the cruelty of Poles towards the Volksdeutsch population in the first days of September 1939. However, as he considered Strauss indirectly guilty of complicity in the crimes committed, Greiner demanded a penalty of 2 years and 9 months in prison for him" (Gazeta Pomorska (24.06.1969), 148, 1, see also: Jaszowski \& Sobecki, 1971, p. 97).

The witnesses in the Strauss trial were: Hans Brook, Erwin Derke, Richard Otto Dey, Willi Ehlert, Lothar Heininger, Rudolf Heininger, Alfred Helmbrecht, Paul Hohmann, Minna Jantz, Helmut Klechowitz, Kazimierz Klewicz, Alojzy Klinkosz, Artur Kozay, Arthur Lange, Kurt Lange, Erich Langner, Alfred Tack, Fritz Zühlke (Archives of the Institute of National Remembrance, reference DS 52/67, photocopy of the judgment in the trial of KF Strauss from 27.06.1969). As was rightly noted in Gazeta Pomorska: "They all live in West Berlin or the German Federal Republic. Most of them are former members of Selbstschutz, whose hands are stained with the crimes committed in the forest of Barbarka" (Gazeta Pomorska (14/15.06.1969), 140,7). The first witness testimony was given by Kurt Lange, a gardener by profession. This former resident of Torun in November 1939 contributed to the arrest of his neighbor, also gardener Feliks Kamiński, and shortly thereafter took over his gardening business. F. Kamiński was interned in Fort VII, then shot in a mass execution in the forest of Barbarka ${ }^{2}$ (Gazeta Pomorska (26/27.04.1969), 98, 7). In contrast to these facts, the witness Lange assured the court that both before the war and during the German occupation of Torun he lived in friendship with the Poles. He talked a lot about the alleged atrocities committed by Poles against the Germans at the end of August and in the first days of September 1939. Lange was a member of Selbstschutz for several weeks, but he served in Fort VII for only two days, after which he was released. Thus he contradicted Strauss's earlier claim that it was impossible to obtain dismissal from duty in Fort VII. Lange admitted to meeting Strauss in Fort VII but claimed to know nothing about his activity there (Gazeta Pomorska (6.06.1969), 133, 1-2; also: Gazeta Pomorska (14/15.06.1969), 140, 7; Jaszowski \& Sobecki, 1971, pp. 90-91). Another witness, 68-year-old Paul Hohmann, who probably from the

2 Feliks Kamiński was shot by Germans in the forest of Barbarka see: Jaszowski \& Sobecki, 1971, pp. 66-68, Grochowina \& Sziling, 2009, p. 22. 
end of October 1939 to autumn 1941 headed the Gestapo branch in Toruń and at the end of 1939 took over control of Fort VII stated that "No one was shot under his authority". Hohmann insisted he did not know what Strauss was doing and what were his competences (Gazeta Pomorska (6.06.1969), 133, 1-2; Jaszowski \& Sobecki, 1971, p. 91). Next to the stand was called Alfred Helmbrecht, born in 1914 in Toruń. He was Strauss' brother-in-law, a blacksmith by profession and a member of Selbstschutz. He admitted to having participated in the executions of Poles in the forest of Barbarka, but he said he was not sure whether he hit anyone. He also claimed he could not say anything about the role played by Strauss in Fort VII. During the investigation, he testified that Strauss boasted to him that he had killed his sister's husband, Hans Hoffman, but in the courtroom he withdrew this testimony (Gazeta Pomorska (6.06.1969), 133, 1-2; see also: Jaszowski \& Sobecki, 1971, pp. 91-92). Alfred Helmbrecht's sister, Minna Jantz (re-married in 1941) was the only female witness in the Strauss trial. Her first husband, Hans Hoffman, as a soldier of the Polish army took part in the September combat, was captured by the Germans and returned to Toruń on September 22, 1939. After a few days, he was arrested by the officers of Selbstschutz and imprisoned in Fort VII. In her testimonies during the investigation, M. Jantz stated that in 1942 she was informed by Strauss that her husband had been executed by a firing squad. Several other witnesses also testified that Hans Hoffman was shot dead because he was a "loyal Polish citizen". However, during the court proceedings in the Strauss trial Jantz declared "she had nothing bad to say about Strauss" (Gazeta Pomorska (6.06.1969), 133, 1-2; see also: Jaszowski \& Sobecki, 1971, pp. 92-93). Witness Erich Langner failed to present himself for the hearing. He sent a letter to the court stating that "there is nothing to add to his testimony provided in the investigation, where he testified that he knew hardly anything about Strauss' crimes. If the court wanted to call him to the stand, he could come testify in August during his vacation" (Gazeta Pomorska (6.06.1969), 133, 1-2). The court found his failure to appear justified. Later in the trial, the testimony given during the investigation by the late Rudolf Heininger was read. Heininger was an employee of the branch of the German Volkslist registry in Torun, and he recounted the mass arrests of Poles in Toruń in October 1939, describing Strauss as "a brutal butcher, whose atrocities were the talk of the entire city. The Germans were also afraid of him and steered clear of Strauss" (Gazeta Pomorska (10.06.1969), 136, 1-2, similarly: Jaszowski \& Sobecki, 1971, pp. 93-94). During the court session on June 12, 1969, the testimony of the late Richard Otto Dey (deceased in 1964) was read. In the years 1936-1942 Dey was a pastor of the Evangelical-Union Church in Torun. In the opinion of pastor Dey Strauss, “(...) was a very important man before the 
war, but he hated Poles with a passion... he did not have a good opinion. Among the Germans, he and Zaporowicz were regarded as the main perpetrators of the VII Fort's executions" (Gazeta Pomorska (13.06.1969), 139, 1-2; also: Jaszowski \& Sobecki, 1971, pp. 94-95; Böhler, Mallmann \& Matthäus, 2009, pp. 149-150). The next witness, Alfred Tack, former officer of Selbstschutz in the course of the earlier investigation testified that he knew about the crimes committed by Strauss in Fort VII and executions in the Barbarka forest, but during the trial "he kept his silence on this subject. This silence lasted almost 40 minutes. The president of the court urged him to recall what he was told by his colleagues Artur Grossman and carpenter Pohl, but the witness pretended that he did not understand what they wanted from him" (Gazeta Pomorska (13.06.1969), 139, 1-2; Jaszowski \& Sobecki, 1971, p. 95). Next to take the stand was Hans Brook, who worked as a bank clerk in Torun before the war. Shortly before German aggression against Poland he left for Gdańsk, and after occupation of Torun by the German troops returned to the city and joined Selbstschutz. He declared that "He did not know much about Strauss, he only remembered that along with Zaporowicz they were tasked with doing the dirty work" (Gazeta Pomorska (13.06.1969), 139, 1-2; see also: Jaszowski, Sobecki, 1971, pp. 95-96). Two more witnesses, Selbstschutz officers Fritz Zühlke and Artur Kozay claimed that "they did not remember anything, they did not know anything about Strauss, and they themselves also did not have any crimes on their conscience" (Gazeta Pomorska (13.06.1969), 139, pp. 1-2). Another witness, the by then late Arthur Lange was a member of the so-called death commando that carried out executions of Poles in the forest of Barbarka. His testimony was read on June 23, 1969. He claimed that after one of the executions he went to SS-Sturmbannführer Zaporowicz with a request for dismissal from duty and soon it was granted (Gazeta Pomorska (24.06.1969), 148, 1; also: Jaszowski \& Sobecki, 1971, p. 96). 63-year-old witness Helmut Klechowitz, a roofer by profession, defended Strauss, claiming that he had released four Poles from Fort VII. As Czesław Sobecki reported: "One could feel that Klechowitz was given clear instructions as to how he should testify. During cross-examination by the prosecution, he admitted that the previous day (i.e. on Sunday) he had talked to Strauss about the trial. How this fact should be taken surely requires no comment" (Gazeta Pomorska (24.06.1969), 148, 1, similarly: Jaszowski \& Sobecki, 1971, pp. 96-97).

The testimonies of priests Kazimierz Klewicz and Jan Klinkosz, incriminating Strauss heavily, were not treated with due consideration (Gazeta Pomorska (21/22.06.1969), 146, 7; (28/29.06.1969), 152, 1-2). Father Kazimierz Klewicz was arrested in the first days of November 1939 in his parish in Biskupice in the 
Torun poviat, was imprisoned first in Fort VII, and then in the camps: Stutthof, Sachsenhausen and Dachau (until liberation on April 29, 1945). After the war, he held a parish in Neuul near Regensburg in Bavaria. According to his account, the hunger in Fort VII was so overwhelming that Strauss allowed some priests interned in Fort VII to go to their parishes and organize a food drive among parishioners. However, after the food was delivered to Fort VII Strauss shared it all between himself and his subordinates (Gazeta Pomorska (10.06.1969), 136, 1-2). Father Alojzy Klinkosz served as a catechist in Tczew until September 1939, and resided in the parish of Saint Joseph. In September he left Tczew, returning after a week, but his flat was taken over by the Germans. To deal with the matter he traveled to Torun, where on October 19, 1939 he was arrested and imprisoned in Fort VII. Subsequently he was held prisoner in the camps: Stutthof, Sachsenhausen and Dachau (until its liberation). After the war he was a pastor in Munich. According to his testimony, he heard Strauss boasting that "already a few years before the war he was spying for the Gestapo, he lived at the time at ul. Wiązowa and reported everything he heard to the German consulate in Torun at Bydgoska Street" (Gazeta Pomorska (10.06.1969), 136, 1-2). According to Klinkosz, Strauss tormented and abused the prisoners of Fort VII and participated in many executions in the forest of Barbarka (Gazeta Pomorska (10.06.1969), 136, 1-2; Jaszowski \& Sobecki, 1971, p. 94). None of the former prisoners of Fort VII were called to provide testimony as eyewitnesses and it was hinted at in the Pomeranian press that "it was not just an ordinary oversight" (Gazeta Pomorska (28/29.06.1969), $152,1-2)$.

On June 25, 1969, the two defenders of the accused took the floor, trying to absolve Strauss of most of the blame, stressing: "It is a stroke of bad luck for Strauss to find himself in the courtroom as the defendant. His colleagues from Selbstschutz, who also took part in the same executions are at large or in the worst case, were called up as witnesses in the trial. Meanwhile, Karl Strauss has to answer for being a loyal German citizen, for following orders of his superiors in the SS" (Gazeta Pomorska (26.06.1969), 150, 1-2). The defense argued that Strauss fell victim to manipulation, was in fact incapacitated and participated in the crimes "out of fear of SS-Sturmbannführer Zaporowicz, who allegedly threatened his subordinates that they would share in the fate of Poles and be handed over to the Gestapo if they were to disobey his orders" (Gazeta Pomorska (26.06.1969), $150,1-2)$. In their opinion, Strauss "for having helped the Poles escape from Fort VII and having arranged food for them should rather hear accolades from the court, not words of condemnation" (Gazeta Pomorska (26.06.1969), 150, 1-2). The defenders, spreading dis-information about the alleged atrocities commit- 
ted by Poles in the first days of September 1939 against the German population also expressed the view that Strauss acted under the influence of these events, in a retaliation attempt for the persecution of Germans living in Poland (Gazeta Pomorska (5.06.1969), 132, 1-2; Jaszowski \& Sobecki, 1971, p. 88). Gazeta Pomorska reported that "The speeches of both defenders were very aggressive in tone. They attacked the West German and West Berlin authorities for pursuing and punishing war criminals while inter alia in England, Poland, Czechoslovakia and the Soviet Union criminals involved in shootings of "innocent Germans" lived at large, and were not brought to answer for their crimes" (Gazeta Pomorska (26.06.1969), $150,1-2)$.

On June 27, 1969, the court pronounced an acquittal in the Strauss case. In the grounds it was stated that Strauss murdered upon orders from his superiors, not on his own initiative, and a refusal to carry out these orders would mean his likely death. Strauss was not even charged with covering the costs of the trial (AINR, reference DS 52/67, photocopy of the judgment in the case of KF Strauss dated 27.06.1969; Gazeta Pomorska (28/29.06.1969), 152, 1-2; see also: Jaszowski \& Sobecki, 1971, p. 99). In the justification of the verdict, Strauss' responsibility was further downgraded, with the court pointing out that before the outbreak of the war, "The accused, a Polish citizen of German origin, speaking fluently both German and Polish, lived in good relations with Poles and treated them without prejudice" (AINR, reference DS 52/67, photocopy of the judgment in the case of KF Strauss dated 27.06.1969). At the same time, the judgement made references to the false stories spread as part of Nazi disinformation campaign, according to which "In the summer of 1939 (...) one could observe the increasingly hostile attitude of Poles towards the Volksdeutch population. Home searches and arrests were carried out against the German inhabitants [of Toruń], and the Polish police refused to protect them (...). After September 1, 1939, violent offenses of Poles against the Volksdeutsches took place in various parts of Poland. Many Germans were murdered in their places of residence (hundreds), as well as during the infamous death march to Warsaw" (AINR, reference DS 52/67, photocopy of the judgment in the case of KF Strauss dated 27.06.1969). During these alleged anti-German actions, several relatives of Strauss reportedly lost their lives; it was hinted that he should be treated as a victim, not the perpetrator.

Strauss' acquittal shocked the Polish public opinion. In the pages of the Pomeranian press, people expressed indignation that "war criminals are tolerated and forgiven for their crimes" and that Strauss himself "came out of the courtroom not as a murderer, but as a "righteous man" that others tried to denigrate and hurt" (Gazeta Pomorska (28/29.06.1969), 152, 1-2). For understandable reasons, 
this scandalous judgement caused particular outrage and sense of injury among the former prisoners of Toruńs Fort VII. Letters of outcry over the acquittal and demands for revision of the trial began to flow to the editorial office of Gazeta Pomorska. Alojzy Dekowski wrote, inter alia: "On June 27, 1969 in the German Federal Republic took place the last epilogue in the farcical trial of the former commander of Fort VII in Toruń, the criminal and sadist KF Strauss. Although the acquittal of this tormentor of Poles was not a surprise, it remains shocking and worthy of condemnation that those who had thrown away any humane feeling and willingly pursued the profession of murderers are so openly protected. I was also a prisoner of Strauss in Fort VII, and even though 30 years have passed since 1939, I can recall Strauss' sadistic exploits perfectly (...). I believe that all of us who were detained in Fort VII feel the need for a collective protest against this acquittal and whitewashing of murderers who left their permanent mark on the world in the form of innocently murdered people (...). All those who passed through the camps and prisons where such as Strauss held power should protest and demand that Strauss be put to re-trial, this time admitting eyewitnesses from Poland and allowing them to take the stand" (Gazeta Pomorska (12/13.07.1969), 164, 7). Józef Donderski from Chełmża appealed: "This criminal and sadist, who has many lives on his conscience, must not escape justice and be allowed to enjoy freedom. His wicked crimes cry for vengeance to the very heavens; this offender whose hands are stained with the blood of defenseless and innocent Poles must be punished (...). This butcher was the embodiments of terror not only to the prisoners of the Fort, but also to our orphaned wives, our distraught mothers, sisters, fathers and brothers, whom Strauss unscrupulously and ruthlessly chased away from the walls of the Fort with a wolfhound and a whip (...). There can never be any absolution for the crimes of Strauss and his companions, and therefore, with a clear conscience, I appeal to our authorities, to the judicial system, to the League of Fighters for Freedom and Democracy, and to you, Sirs, to demand extradition of Strauss and his exemplary punishment" (Gazeta Pomorska (26/27.07.1969), 176, 7-8).

There is no doubt that after 1945 the German judicial system did not fulfill its obligations as concerns prosecution and punishment of Nazi war criminals. The trial of Karl Friedrich Strauss is one of numerous examples of failure of the denazification process, which has led neither to removal of Nazis from German public life nor to their punishment. Professor Anna Wolff-Powęska, author of the book Memory - the Burden and the Unburdening. Germany Against Its Nazi Past (1945-2010) (orig. in Polish: Pamięć-brzemię i uwolnienie. Niemcy wobec nazistowskiej przeszłości (1945-2010)), rightly calls denazification "a failed experiment" (for more see: Wolff-Powęska, 2011). 
Although in the opinion of eyewitnesses, former prisoners of Fort VII the crimes committed by Strauss were not subject to any doubts, nevertheless the officers of the German justice system lacked determination and meticulousness in pursuing a fair judgment in this case. There are many indications that they simply were not overly concerned with the outcome. The leniency of the judges meant that the criminal proceedings against Strauss left much to be desired. The witnesses called in the Strauss trial were largely former Selbstschutz officers, rules by the code of silence. Meanwhile - what seems quite obvious - the court should have first called as witnesses and took into account the testimonies of direct victims of Strauss' crimes. In the courtroom, the justification given by both Strauss and his defenders sounded positively grotesque. The defenders in their cynical statements tried to prove that the accused was not directly responsible for the crimes, and instead pointed to the dualism of his actions, in that Strauss had to follow orders even when it required participation in executions of Poles, but that - allegedly he tried to help them as well. Strauss himself, like other was criminals, denied the accusations and downplayed his own guilt by shifting responsibility onto his immediate superiors. Looking at the Strauss trial, one cannot resist reflection that the German judiciary of the time seems to have joined in the campaign of leniency for the Nazis, whitewashing their crimes and covering up the "brown past" instead of pursuing a true reckoning. Thus one of the greatest tormentors of the prisoners in Toruń's Fort VII, whose crimes were blatantly evident, in the end evaded justice and could enjoy freedom. The human justice has failed, and thousands of such unpunished criminals remained at large.

\section{References:}

Böhler, J., Mallmann, K. M., Matthäus, J. (2009). Einsatzgruppen w Polsce. Warszawa: Bellona.

Bojarska, B. (1979). Selbstschutz w Okręgu Gdańsk-Prusy Zachodnie. Biuletyn Gtównej Komisji Badania Zbrodni Hitlerowskich w Polsce, XXIX.

Frei, N. (1999). Polityka wobec przeszłości. Początki Republiki Federalnej i przesztość nazistowsk. Warszawa: Wydawnictwo Trio.

Grochowina, S. \& Kącka, K. (2014). Foundations of Nazi Cultural Policy and Institutions Responsible for Its Implementation in the Period 1933-1939. Kultura i Edukacja, 6, 173-192. DOI: 10.15804/kie.2014.06.10.

Grochowina, S. \& Sziling, J. (2009). Barbarka. Miejsce niemieckich egzekucji Polaków z Torunia i okolic (październik-grudzień 1939). Toruń: Fundacja Generał Elżbiety Zawackiej. Archiwum i Muzeum Pomorskie Armii Krajowej oraz Wojskowej Służby Polek. 
Jansen, Ch. \& Weckbecker, A. (1992). Der „Volksdeutsche Selbstschutz” in Polen 1939/40. München: R. Oldenbourg Verlag.

Mazanowska, I. \& Ceran, T. (eds.). (2016). Zapomniani kaci Hitlera. Volksdeutscher Selbstschutz w okupowanej Polsce 1939-1940. Wybrane zagadnienia. Bydgoszcz-Gdańsk: Instytut Pamięci Narodowej. Komisja Ścigania Zbrodni przeciwko Narodowi Polskiemu Oddział w Gdańsku.

Sołga, H. (2004). Niemcy. Sądzący i sadzeni 1939-2000. Kraków: Wydawnictwo Ikon.

Taylor, F. (2016). Wypędzanie ducha Hitlera. Okupacja i denazyfikacja Niemiec. Wołowiec: Wydawnictwo Czarne.

Vollnhals, C. \& Schlemmer, T. (1991). Entnazifizierung. Politische Säuberung und Rehabilitierung in den vier Besatzungszonen 1945-1949. München: Deutscher Taschenbuch Verlag.

Wahl, A. (2009). Druga historia nazizmu w federalnych Niemczech po 1945 roku. Warszawa: Wydawnictwo Akademickie Dialog.

Wolff-Powęska, A. (2011). Pamięć-brzemię i uwolnienie. Niemcy wobec nazistowskiej przeszłości (1945-2010). Poznań: Wydawnictwo Zysk i S-ka.

\section{Press:}

Gazeta Pomorska: (22/23.03.1969), 69; (25.03.1969), 71; (26.03.1969), 72; (29/30.03.1969), 75; (26/27.04.1969), 98; (5.06.1969), 132; (6.06.1969), 133; (7/8.06.1969), 134; (10.06.1969), 136; (13.06.1969), 139; (14/15.06.1969), 140; (21/22.06.1969), 146; (24.06.1969), 148; (26.06.1969), 150; (28/29.06.1969), 152; (12/13.07.1969), 164; (26/27.07.1969), 176 .

\section{Archival sources:}

Archives of the Institute of National Remembrance, reference GK 164/608, vol. 1, warrant for temporary arrest of KF Strauss of 29.12.1947.

Archives of the Institute of National Remembrance, reference GK 351/161, extradition request in the case of K. F. Strauss of 21.01.1948.

Archives of the Institute of National Remembrance, reference DS 52/67, photocopy of the judgment in the KF Strauss case of 27.06.1969. 